DOI 10.14746/ssp.2018.2.11

\author{
Natalia KLEJDYSZ
}

Uniwersytet im. Adama Mickiewicza w Poznaniu

\title{
Bunt kobiet: w poszukiwaniu źródel świadomości równościowej (od XVII do lat 60. XX wieku)
}

Streszczenie: XX wiek bywa nazywany „stuleciem kobiet”. Feminizm drugiej fali, poprzedzony zaangażowaniem sufrażystek i ich skuteczną walką o prawa polityczne, doprowadził do przyspieszenia procesu kształtowania samoświadomości kobiet. Wszelako proces ten rozpoczął się znacznie wcześniej. Dziewiętnastowieczne protesty emancypantek poprzedzała stuletnia historia buntów kobiet. Wprawdzie ich motywacja na etapie siedemnasto- i osiemnastowiecznych kontestacji miała przede wszystkim charakter ekonomiczny i polityczny, a działania te były wspomagające względem aktywności mężczyzn, lecz rodziła się już wówczas refleksja nad nieekwiwalentnością społecznego wkładu kobiet i ich rzeczywistej partycypacji. Niniejszy artykuł jest zatem poświęcony owym nieśmiałym początkom odradzającej się świadomości równościowej, wyrażanej w różnych formach buntu i protestu.

Słowa kluczowe: feminizm, kobiety, ruchy społeczne, protest społeczny, świadomość równościowa, równouprawnienie

Ayndrom Ewy determinujący judeochrześcijanską narrację o kobiecie przez dwa tysiąclecia stanowił podstawę patriarchalnej koncepcji społeczeństwa. Mimo że interpretacji boskiej kreacji człowieka było wiele, to do powszechnej świadomości przedostała się ta, zakładająca wtórność i niedoskonałość kobiety. Jej marginalizacja, a nawet odczłowieczenie było konsekwencją dopatrywania się winy za upadek człowieka, właśnie w Ewie. To ona zatem jest „twórczynią” grzechu, to ona więc ponosi moralną odpowiedzialność za ukrzyżowanie Zbawiciela. Mimo że w judaizmie akt nieposłuszeństwa nie skutkował grzechem pierworodnym, to seksualność kobiety jest karą za inspirację. W wykładni rabinicznej Ewa i jej następczynie zostały obłożone dziewięciorgiem przekleństw, wśród których jest ból menstruacyjny i utraty dziewictwa, uciążliwość ciąży i męczarnia porodu. Zatem to, co w sensie esencjalnym określa kobiecość, stanowi podstawę dyskryminacji i marginalizacji kobiet. Podtrzymywanie i rozwijanie owego mitu miało więc dla mężczyzn znaczenie 
utylitarne, ponieważ pozycjonowało kobiety w sposób niezagrażający ich władzy. W tym kontekście, ograniczenie sensu kobiecej egzystencji do wymiaru prokreacyjnego, było wprawdzie przejawem niekonsekwencji w interpretacji Pisma, ale usprawiedliwiało korzystanie ze swej seksualności mężczyznom.

W ten sposób świat kobiety został ograniczony do sfery natury, mężczyzny - rozumu. A że rozum winien panować nad naturą, kobieta winna posłuszeństwo mężczyźnie. Przeświadczenie o emocjonalnym rozchwianiu kobiet determinowało przez wieki aprioryczne sądy i przekonania. Przypadki kobiet wybitnych traktowano jako „wybryk natury”, nadając mu rangę mistyczną lub diaboliczną.

Protesty kobiet tak w przeszłości, jak i współcześnie, mają więc wymiar korporalny. Pojęcia tego używam w innym sensie niż czyni to Elizabeth Grosz, aczkolwiek wychodząc poza esencjalny wymiar seksualności. Inaczej rzec ujmując, manifestacja poglądów bądź uczuć przez kobiety, jest ściśle powiązana $\mathrm{z}$ seksualnością, zarówno w wymiarze biologicznym, jak i psychologicznym czy też społecznym. Wprawdzie korporalny wymiar protestów uwidacznia się przede wszystkim od lat 60 . XX wieku, ale jego aspekty możemy dostrzec również w podobnej aktywności kobiet w wieku XVII, kiedy to po raz pierwszy mamy do czynienia z taką formą aktywności.

Siedemnastowieczne rewolty miał bezpośredni związek z przemianami kapitalistycznymi i polityką ogradzania (Zemon Davis, 1975, s. 146), co doprowadziło w konsekwencji do migracji ludności wiejskiej do miast i spadku wartości siły roboczej. Jednak pierwszy odnotowany protest kobiet dotyczył budowy kanału odwadniającego. W 1603 roku około 200 kobiet, stając w obronie swych gospodarstw, zagroziło „kapitanowi” kanału śmiercią (Bogucka, 2005, s. 192-196).

Kolejne wystapienia miały miejsce w 1630, 1638, 1641 i 1642 roku. Źródłem determinacji kobiet były, sytuujące się ponad płcią ${ }^{1}$, problemy gospodarcze. Zatem nie wzrost świadomości równościowej, lecz potrzeba przetrwania były katalizatorem rewolty. Uczestniczkami rewolty chłopskiej były więc kobiety z najniższych warstw społecznych. Walka o cele polityczne stała się raczej atrybutem kobiet protestujących w miastach (Bogucka, 2005, s. 197). W tym kontekście warto również zwrócić uwagę

${ }^{1}$ Zdaniem Natalie Zemon Davis protesty kobiet w XVII wieku nie były pozbawione kontekstu płci. Wiąże się to jednak z groteskowością sytuacji - jako że kobiety, jako istoty słabsze i niedorównujące mężczyznom, cieszyły się czymś w rodzaju „licencji” na niewłaściwe zachowanie (Zemon Davis, 1975, s. 146). 
na wydarzenia, które miały miejsce w 1637 roku w Edynburgu. Blisko osiemdziesiąt lat wcześniej powstał Kościół Szkocki, który wprawdzie opierał się na doktrynie kalwinizmu, ale jednocześnie miał charakter episkopalny. Ani Jakub I, ani jego syn - Karol I nie ustawali w staraniach narzucenia Kościołowi Szkockiemu anglikańskich form liturgii. W tym celu opracowano szkocką wersję „Modlitewnika Powszechnego” („Księga Wspólnych Modlitw”), która miała zostać ogłoszona w lipcu 1637 roku w edynburskiej katedrze. Jednak gdy tylko dziekan zaczął odczytywać słowa Księgi, miejscowa przekupka, Jenny Geddes, rzuciła stołkiem² w biskupa Edynburga, a gdy wyprowadzono ją z kościoła, obrzuciła kamieniami katedralne drzwi i okna (Zemon Davis, 1975, s. 146).

To wydarzenie przyczyniło się do wybuchu powstania szkockiego, a w dalszej perspektywie - rewolucji burżuazyjnej w Anglii, w której wzięły udział również kobiety. Ich zaangażowanie odnotowano po obu stronach sporu - wśród rojalistów oraz ugrupowań Długiego Parlamentu: zbierały fundusze, były szpiegami ${ }^{3}$ i emisariuszkami ${ }^{4}$, broniły zamków pod nieobecność mężczyzn, a nawet działały na rzecz armii ${ }^{5}$ (Bogucka, 2005, s. 196-197).

Jednak cele owej aktywności nie miały znaczenia dystynktywnego i konsolidującego, nawet w wymiarze doraźnym. Należy jednak zwrócić uwagę na wydarzenia roku 1643. Odrzucenie przez Izbę Gmin nieznaczną większością głosów, opracowanej przez Izbę Lordów, propozycji rozejmu z Karolem I, spotkało się z negatywnym odbiorem, zmęczonych przeciagającą się wojną domową, londyńczyków. 8 sierpnia, pod siedzibą Parlamentu, zgromadziło się kilkaset kobiet, manifestujących na rzecz pokoju. Uspokojone ustnymi zapewnieniami rozpatrzenia ich żądań, rozeszły się do domów. Jednak następnego dnia pod Pałacem Westminsterskim zgromadziło się kilka tysięcy kobiet $^{6}$, ubranych w kapelusze przy-

2 Trójnogie stołki wykorzystywano w Kościele Szkockim w celach pokutnych - musiał nań usiąść wyczytany przez dziekana winowajca i publicznie się ukorzyć (Reid, 1834, s. 217).

${ }^{3}$ Na przykład Constance Springer.

${ }^{4} \mathrm{Na}$ przykład Elizabeth Alkin.

5 Elizabeth Poole bywa określana mianem ,doradczyni” Rady Generalnej Armii, co jednak jest znacznym nadużyciem, ponieważ Pool jedynie (aż?) występowała (w 1648 roku) przed Radą z profetycznym sprzeciwem wobec egzekucji Karola I (patrz więcej: Font Paz, 2013).

${ }^{6}$ Dziennikarz John Dillighan, twierdził, że pod Parlamentem zebrało się około 6 tys. kobiet, wśród których większość stanowiły żony żołnierzy, a jedną dziesiątą - prostytutki. Bardzo dosadnie określił protestujące kobiety Richard Collings, par- 
ozdobione, na znak pokoju, białymi wstążkami. Oczekiwały spotkania $\mathrm{z}$ przywódcami parlamentarnymi w celu przedstawienia im The Petition of Many Civil Disposed Women (Allen, 1827, s. 366). Parlamentarzyści, zapoznawszy się z jej tekstem, ponownie wydali uspokajające oświadczenie, które jednak tym razem nie przyniosło oczekiwanego rezultatu - kobiety zablokowały wejście do Parlamentu. W efekcie doszło do dramatycznej konfrontacji uczestniczek pokojowej demonstracji z żołnierzami konnego pułku Williama Wallera ${ }^{7}$.

Istnieją wątpliwości czy protest kobiet z 1643 roku był spontaniczną akcją w obronie pokoju, czy zorganizowaną manifestacją polityczną, w której kobiety zostały wykorzystane ${ }^{8}$. Prawdopodobnie pierwsze zgromadzenie, które miało miejsce 8 sierpnia, było żywiołową demonstracją kobiet zatroskanych losami walczących w wojnie domowej mężczyzn. Jednak można wątpić w spontaniczność wydarzeń 9 sierpnia. Po pierwsze, skoro ich uczestnikami były przede wszystkim kobiety niskiego stanu, a więc ubogie i niepiśmienne, kto przygotowałby przedłożoną Parlamentowi Petycję. A po drugie, na zorganizowany charakter protestu wskazuje również fakt, iż uczestniczki miały przy sobie białe wstążki, które symbolizowały pokojowe cele. Analizując intencje protestujących, trudno rozstrzygnąć jakie były przesłanki zgromadzeń. $Z$ jednej bowiem strony uderza ich polityczny wymiar, jednak z drugiej - dostrzegamy ich tło ekonomiczne: żądającym zaprzestania wojny domowej kobietom raczej nie chodziło o abstrakcyjną ideę pokoju, lecz powrót do domów jedynych żywicieli rodziny.

Sprzyjającym w procesie odzyskiwania świadomości równościowej czynnikiem był polityczny ferment $\mathrm{w}$ okresie rewolucji burżuazyjnej ${ }^{9}$.

lamentarzysta i dziennikarz; stwierdził, że w przeważającej mierze były to „dziwki, rajfurki, ostrygarki, pomoce kuchenne, żebraczki, a poza tym wiele szumowin z przedmieść, oprócz pewnej liczby Irlandek” (cyt. za: Read, 2015, s. 6).

${ }^{7}$ Brak jednoznacznej informacji na temat liczby ofiar. Sara Read pisze, że na pewno zginęło dwoje ludzi (dwóch mężczyzn? - „two men”; przywołana przez Read relacja naocznego świadka, Johna Normana, świadczy, że wśród ofiar śmiertelnych były również kobiety), a wiele kobiet i mężczyzn zostało rannych (Read, 2015, s. 6). Natomiast Maria Bogucka twierdzi, że ,według niektórych zabito kilka kobiet, według innych szacunków około stu (Bogucka, 2005, s. 198).

${ }^{8}$ Podobne wątpliwości budzą wystąpienia E. Poole przed Radą Generalną Armii (Font Pas, 2013, s. 185-187).

9 Według Briana Manninga niezadowolenie, wynikające ze społecznej dyskryminacji, kobiety odczuwały już wcześniej, przed wybuchem wojny domowej (Manning, s. 178). Te słowa zdają się potwierdzać przywołane przykłady pierwszych kobiecych 
Postępująca radykalizacja poglądów uczestników rewolucji, zaowocowała wewnętrznymi konfliktami i podziałami. W ich wyniku ze środowiska independentów wyłoniła się grupa radykałów, z Johnem Lilburnem na czele. Oliver Cromwell nazwał ich wyrównywaczami (levellers). I mimo że Lilbure'owi daleko do komunistycznego zaangażowania Gerrarda Winstanleya, to złośliwie wypowiedziane przez lorda protektora określenie jest szczególnie adekwatne, gdy mowa o relacjach płci. W artykule The Freemans Freedom Vidicated z 1646 roku Lilburne przyjmuje jako punkt wyjścia boskie pochodzenie człowieka. Akt kreacji czyni kobiety i mężczyzn z natury równymi co do godności i autorytetu. Zatem żadna płeć (z natury) nie ma władzy i nie sytuuje się ponad drugą. Tylko obopólna zgoda, wyrażona w imię wspólnych korzyści, legitymizuje, oparte na hierarchii władztwo. Z drugiej jednak strony musimy mieć na względzie to, że dla lewelerów kryterium partycypacji politycznej było „,samodecydowanie". Ta zasada wykluczała więc z grona uprawnionych do głosowania służbę i kobiety, gdyż nie decydowali sami o sobie ${ }^{10}$ (Delonette, 2002, s. 39-40).

Dla Winstanleya z kolei przejawem wolności jest możliwość wyboru współmałżonka, tak przez mężczyzn, jak i przez kobiety. Wszelkie próby siłowego narzucenia woli, powinny być karane śmiercią. Gwałt godzi bowiem w podstawowe prawo człowieka, jakim jest wolność, a zniewoleniu podlega ciało kobiety. Ewangeliczna koncepcja równości, w ujęciu diggerów, wykracza nie tylko poza płeć, ale również pochodzenie społeczne i stan majątkowy. Podwójnemu zniewoleniu, jakiemu podlegała kobieta wywodząca się z nizin społecznych, Winstanley przeciwstawia ,podwójne wyzwolenie" - mężczyzna ma obowiązek poślubić kobietę, z którą spłodził dziecko, bez względu na jej status społeczny (Winstanley, 1652).

Słyszalność kobiet, czy to tych, które protestowały przeciwko odbieraniu ziemi, czy tych, które poprzez petycje usiłowały wpływać na politykę Parlamentu, w spatriarchalizowanym społeczeństwie zależała od poparcia mężczyzn. Zyskując wsparcie Lilburne'a czy Winstanleya, mimo że ich radykalizm sytuował lewelerów i diggerów na marginesie sceny politycznej ${ }^{11}$, stawały się aktorami kształtującego się ruchu społecznego.

protestów, aczkolwiek, jak już wspomniałam, trudno im przypisywać motywację równościową.

10 Jednak, zgodnie $\mathrm{z}$ tą zasadą, prawo do głosowania przysługiwałoby wdowom i starym pannom.

11 Wprawdzie do 1649 roku wpływ lewelerów na armię był znaczący, a udział w Parlamencie dostrzegalny, jednakże sytuacja zmieniła się po egzekucji Karola I. 
W XVIII wieku myślowa dojrzałość, która ujawniła się w samodzielności dociekań, pozwoliła również na rozwinięcie się świadomości równościowej. Nowożytna koncepcja prawa natury, kształtująca się od XVII wieku, stała się teoretyczną podstawą dwóch kluczowych dla historii dokumentów: Deklaracji Niepodległości i Deklaracji Praw Człowieka i Obywatela.

Udział kobiet w obu rewolucjach, amerykańskiej i francuskiej, był konsekwencją rozwijającej się świadomości obywatelskiej. Zaangażowanie kobiet w działania zbrojne może być uznane jako przejaw obywatelstwa. Jest nim również powoływanie stowarzyszeń obywatelek ${ }^{12}$, które wszelako podejmowały walkę z arystokracją, lecz nie w obronie kobiet.

Natomiast petycja kobiet stanu trzeciego, skierowana do króla w 1789 roku jest dowodem na formujący się egalitaryzm płci. W licznych, nie tylko anonimowych, pismach, które ukazywały się w czasie francuskiej rewolucji, coraz częściej, obok uniwersalnych postulatów ekonomicznych, pojawiały się żądania, których podmiotem były kobiety. Wykraczały one poza sferę prywatną, pozycjonując je jako uczestniczki życia społecznego. Kształtującej się świadomości obywatelskiej i równościowej kobiety dały wyraz już przed zwołaniem Stanów Generalnych, a więc przed majem 1789 roku. Włączyły się w akcję redagowania postulatów, tworząc własne „Księgi skarg kobiet” (,, Cahiers des doléances des femmes”). „Domagają się równego dostępu do edukacji; uważają, że należy im się prawo do dziedziczenia; nie chcą być dłużej traktowane jako towar handlowy, żądają więc zniesienia posagu, twierdząc, że to mąż powinien im zapewnić utrzymanie; na koniec mówią, że zdrada małżonka powinna być karana tak samo jak zdrada żony" (Wysłobocki, 2010, s. 2).

Ten głos, mimo swej siły, pozostawał jednak niesłyszalny, choć nie należy pomijać tych, którzy w obronie kobiet stawali, krytykując hipokryzję rządzących (np. Condorcet, Charles-Guillaume Théremin, Pierre Guyomar, Charles-Louis Rousseau). Nie kwestionując kobiecego posłannictwa macierzyńskości, opowiadali się za przyznaniem kobietom równoprawności w życiu publicznym, a więc za ich ,pełną obywatelskością”. Rzecz w tym, by równość płci nie ograniczała się jedynie do obowiązków

W marcu, nowo powołana Rada Państwa wydała nakaz zatrzymania przywódców (Liburna, Overtona i Prince'a) pod zarzutem zdrady stanu. Kolejne aresztowania, konfiskaty pism i zakaz ich drukowania oraz represje wobec zwolenników Lilburne'a spowodowały załamanie się ruchu (Rees, 2014, s. 114-115).

${ }^{12}$ Na przykład francuskie Towarzystwo Rewolucyjnych Obywatelek Republikańskich założone w 1793 roku, a powiązane z sankiulotami. 
i odpowiedzialności, lecz by miała również przełożenie na równość praw (Wysłobocki, 2013, s. 225-226).

Mimo zaangażowania w walkę z absolutystycznym reżimem, w 1791 roku okazało się, że opracowując Deklarację Praw Człowieka i Obywatela, o kobietach zapomniano. Medale od burmistrza Paryża za udział w walce nie przyniosły kobietom wymiernych korzyści. Na nic zdał się marsz kobiet na Wersal 5 i 6 października, choć, paradoksalnie, to dzięki niemu Ludwik XVI powrócił do Paryża i podpisał Deklarację. Wszelako wersalskie wydarzenie było symptomatyczne. Nie tylko bowiem sam fakt, iż przewodziły mu kobiety ${ }^{13}$, ale forma i skutki ich zaangażowania były symptomatyczne. Określenie „niezadowolenie” nie oddaje nastrojów, które towarzyszyły uczestniczkom „Październikowych Dni”"14; właściwsze będą: furia i wściekłość, „dzikość” (Wysłobocki, 2010, s. 3). Pokonując drogę między Paryżem a Wersalem, wzbudzają nie tylko zainteresowanie, ale również strach - mordują strażników królewskiego pałacu, a ich głowy nabijają na piki. Tak ,,uzbrojone” wkraczają do pałacu. Jak podkreśla Wysłobocki, zaskakujące jest to, że nie tylko uzyskują audiencję u króla, ale również przedstawiają mu swoje postulaty. Niezwykłość owego wydarzenia podkreśla również fakt, że wśród uczestniczek marszu przeważały kobiety niskiego stanu: handlarki, praczki, wieśniaczki. $\mathrm{Z}$ tego powodu interpretacja motywacji uczestniczek Marszu na Wersal nie jest jednoznaczna. $Z$ jednej bowiem strony można założyć, że udział w październikowych wydarzeniach był spowodowany trudną sytuacją ekonomiczną z drugiej jednak mamy wszelkie podstawy, by wnioskować, iż było to autentyczne zaangażowanie polityczne, u podstaw którego sytuowała się świadomość obywatelska. Z kolei, powołując się na Olwen Huston, David Garrioch twierdzi, iż wprawdzie centralną kwestią były dostawy chleba, lecz równie mocno należy podkreślić polityczny wymiar Październikowego Marszu (Garrioch, 1999, s. 233). Wszelako rozłożenie akcentów zależy od czasowej perspektywy i włączenia w tę ocenę kolejnych zdarzeń (Garrioch, 1999, s. 248).

O kobietach zapomniano nie tylko w Deklaracji, ale również w obu konstytucjach - z 1791 i 1793 roku. Wprawdzie, dzięki zaangażowaniu

13 Wprawdzie również mężczyźni brali w nim udział, lecz trzymali się z tyłu, zachowując jak tchórze (Garrioch, 1999, s. 232). Jednak wiele wskazuje na to, że ten sposób organizacji marszu nie był przypadkowy - chodziło o to, by postrzegano go jako inicjatywę pokojową.

14 Obok „Marszu na Wersal”, „Październikowego Marszu”, określenie „Październikowe Dni” jest kolejnym stosowanym w odniesieniu do omawianych wydarzeń. 
Cercle Social ${ }^{15}$, z Condorcetem na czele, wprowadzono rówoprawność dziedziczenia i prawo kobiet do rozwodu, ale rozważania nad prawami politycznymi utknęły na poziomie rozmyślań nad tym czy kobieta jest człowiekiem i obywatelem (Bogucka, 2005, s. 202), a opublikowanie Deklaracji Praw Kobiety i Obywatelki w 1791 roku, Olimpia de Gouges przypłaciła życiem. W 1793 roku wstąpiła na szafot wraz z Marią Antonina, Charlotte de Cordey, zabójczynią Jeana-Paula Marata, oraz Madame Roland ${ }^{16}$. Ta ostatnia ,zawiniła” prowadząc salon polityczny, pisząc przemówienia swemu mężowi, postulując prawo kobiet do edukacji. Jakże niepopularna wśród ówczesnej elity władzy musiała być jej krytyka terroru rewolucyjnego, o którym pisała, iż jest bardziej okrutny „od despotyzmu, na którego ruinach powstał”17 (cyt. za: Głażewski, 2013, s. 50).

Mniej tragiczny los spotkał Ettę Palm d'Aelders, która była wprawdzie Holenderka, lecz po nieudanym małżeństwie zamieniała Amsterdam na Paryż. Niezależność finansowa ${ }^{18}$ pozwoliła jej na aktywną działalność na rzecz praw kobiet - powołała Patriotyczne i Dobroczynne Towarzystwo Przyjaciółek Prawdy, założyła salon dyskusyjny, który nie tylko stał się miejscem spotkań filozofów i polityków, ale był również czymś na kształt wszechnicy edukacyjnej dla kobiet. Jako orędowniczka równouprawnienia kobiet i mężczyzn w małżeństwie, uczestniczyła również w agitacji na rzecz rozwodów (Pomianowski, 2016, s. 779). W 1790 roku Etta Palm wygłosiła przed Zgromadzeniem Narodowym słynną mowę zatytułowaną „Dyskurs o niesprawiedliwości praw na rzecz mężczyzn kosztem kobiet”, gdzie ubolewała nad sytuacją, w której „mężczyzna stał się panem, który najświętszy z obowiązków - bycie żoną i matką - zmienił w ciężkie i straszne niewolnicze zadanie (cyt. za: Wysłobocki, 2013, s. 225). Trudno dziś jednoznacznie stwierdzić czy zasądzona kara więzienia była konsekwencją jej działalności feministycznej, czy też zaangażowania politycznego, wszelako w 1795 roku Etta Palm została osadzona w twierdzy Woerden. Zmarła wkrótce po opuszczeniu więzienia (w 1799 roku).

15 W Cercle Social wyodrębnił się klub kobiet nazywany „Przyjaciółki Prawdy”. Podobne kluby powstawała również w innych miastach.

16 Wszystkie trzy kobiety zginęły w tym samym, 1793, roku.

17 Cytat ten pochodzi z Mémoires particulier, które powstały już podczas jej pobytu w więzieniu.

18 Zawdzięczała ją pracy na rzecz wywiadu francuskiego, dla którego szczególnie cenne były jej bliskie kontakty z prominentnymi politykami. 
Jedną z bardziej znanych i oryginalnych aktywistek feministycznych doby rewolucji francuskiej była również Théorgine de Méricourt ${ }^{19}$. Wzbudzała zainteresowanie nie tylko oryginalnym strojem, lecz również gorliwością rewolucyjną, choć ani nie brała udziału w ataku na Bastylię, ani nie uczestniczyła w Październikowych Dniach. Była jednak wśród witających Ludwika XIV po jego powrocie z Wersalu. Już wówczas ubierała się w strój do jazdy konnej i kapelusz z okragłym rondem. Mimo że początkowo jej zaangażowanie obywatelskie było nieznaczne, została oskarżona o udział w Marszu. Obawiając się aresztowania, zdecydowała się opuścić Paryż. Podczas ucieczki dostała się do niewoli austriackiej w związku z podejrzeniem o udział w przygotowywaniu zamachu na Marię Antoninę. Dzięki wstawiennictwu przyjaciół odzyskała wolność (Walton, 2016). Powróciła więc do stolicy, gdzie w pełni zaangażowała się w działalność rewolucyjną: próbowała założyć klub dla kobiet, namawiała je również do stworzenia oddziału milicji, ponieważ, jak twierdziła, już najwyższy czas, by położyć kres niewoli kobiet, utrzymywanej męską ignorancją, pychą niekompetencją i niesprawiedliwością, brała również udział w walkach o dzielnicę Tuileries (Abray, 1980, s. 242). Oskarżenie Théorgine o oszustwo oraz publicznie deklarowane poparcie dla żyrondystów spowodowały spadek jej popularności w Paryżu. W 1793 roku tuż przed planowanym przemówieniem na Tarasie Feuillants została zaatakowana przez zwolenniczki jakobinów. Kobiety rozebrały ją do naga i dotkliwie pobiły. Wydarzenie to dramatycznie wpłynęło na dalsze losy Anne Terwagne - cierpiąc na bóle głowy i problemy psychiczne dwadzieścia lat spędziła w szpitalu (Walton, 2016).

Do grona paryskich radykałek włączyła się również Anne Pauline Léon, która wraz z Claire Lacombe w 1793 roku założyła Towarzystwo Rewolucyjnych Obywatelek Republikańskich. Najogólniej rzecz ujmując, celem organizacji była walka o prawa kobiet. Jednak rzecz w tym, że Obywatelki dążyły przede wszystkim do natychmiastowej realizacji postulatów, a więc dopuszczenia Paryżanek do uczestnictwa w polityce rewolucyjnej. Powołanie Towarzystwa było naturalną konsekwencją wcześniejszej aktywności społeczno-politycznej Léon ${ }^{20}$ : uczestniczyła

19 Prawdopodobnie jej prawdziwe nazwisko to Anne Terwagne, ale w Paryżu była znana również jako Mademoiselle Campinados. Ten pseudonim przyjęła parając się prostytucją (Walton, 2016).

20 Zasługi Pauline Léon w niczym nie przewyższają tych, które możemy przypisać Claire (Rose) Lacombe - francuskiej aktorki, która politykę przedłożyła nad scenę (wprawdzie, jako aktorka, zyskała popularność na prowincji, jednak po przybyciu do 
w zdobyciu Bastylii, była również zaangażowana w działalność Kordelierów (Towarzystwa Przyjaciół Praw Człowieka i Obywatela) oraz Towarzystwa Patriotycznego. W maju 1793 roku Pauline Léon wystapiła przed Zgromadzeniem Narodowym z petycją ${ }^{21}$, dotycząca powołania kobiecej Gwardii Narodowej. W tym samym roku poślubiła, związanego ze środowiskiem „Wściekłych”, Théophile'a Leclerca ${ }^{22}$. Wkrótce oboje zostali aresztowani w związku z podejrzeniem sympatii prohebertystycznych. Niewiele wiemy o jej kilkumiesięcznym pobycie w więzieniu, jednak pośrednim źródłem informacji o jej losie może być wypowiedź, z której wynika, że dla Léon ,podstawą miłości Ojczyzny” jest „miłość małżeńska i cnoty domowe” (Levy, Applewhite, Johnson, 1980, s. 160). Biorąc pod uwagę jej wcześniejsze poglądy, można domniemywać, że oświadczenie było konsekwencją presji, a nie osobistych przemyśleń.

Działalność Pauline Léon jest doskonałym przykładem dysonansu panującego we francuskim środowisku prorepublikańskim, a wynikającego $\mathrm{z}$ odmiennego spojrzenia na rolę kobiet w ruchu rewolucyjnym. Zresztą sama Léon, abstrahując od więziennego listu, niejednoznacznie określała swe cele, choć niewątpliwie na pierwszym planie stawiała walkę z tyranią króla i arystokracji. Z drugiej jednak strony twierdziła, że „kobiety muszą być częścią rewolucji i Republiki oraz odgrywają integralną rolę w przyszłości Francji”. Jednak innym razem definiowała kobiecą naturę jako syntezę „odwagi i niezłomności” oraz naturalnej „słabości” (Proctor, 1990, s. 48-50). Pomiędzy potrzebą partnerstwa a presją patriarchalizmu, wolnością i bezpieczeństwem, świadomością i uległością - w tym obszarze rozgrywa się akcja spektakularnej walki francuskich kobiet w imię równości.

Zaangażowanie i determinacja rewolucjonistek - feministek francuskich nie przyniosła długotrwałych efektów. Można odnieść wrażenie, że przyzwolenie niektórych środowisk prorepublikańskich wobec uczest-

Paryża jej kariera sceniczna stanęła pod znakiem zapytania). Wręcz przeciwnie - Lacombe występowała przed Zgromadzeniem Ustawodawczym, brała udział z bronią w ręku w szturmie na pałac królewski w Tuileries. Tak jak Léon, ona również została aresztowana i spędziła w więzieniu ponad piętnaście miesięcy. Po odzyskaniu wolności opuściła wprawdzie na pewien czas Paryż, jednak wkrótce powróciła do stolicy, wszelako nie podejmując już aktywności politycznej (Godineau, 1998, s. 390-391).

${ }^{21}$ Petycję tę podpisało 320 Paryżanek.

${ }^{22}$ Zastanawiająca jest relacja między Leclerkiem, Léon i Lacombe. Claire Lacombe była wcześniej kochanką Leclerca, a ślub z Léon był dla wielu osób zaskoczeniem (Moore, 2008, s. 230; Godineau, 1998, s. 390). 
nictwa kobiet w politycznych wydarzeniach tamtych czasów, wynikało z instrumentalizacji kobiecej aktywności. Poparcie i udział kobiet były cenne przede wszystkim ze względów ilościowych, w mniejszym stopniu - jakościowych. Dlatego też „wygaszaniu rewolucji” towarzyszyło osłabienie impetu starań na rzecz społeczno-politycznego awansu kobiet. Skutki owych zaniechań stały się odczuwalne stosunkowo szybko, bo już na początku stulecia, choć dzięki rewolucji kobiety wywalczyły prawo rozwodowe, które pozwalało im uniknąc , przymusowych małżeństw” czy „domowego niewolnictwa” (Bessiéres, Niedzwiecki, 1991, s. 18).

Mniej spektakularną formę przybrał udział kobiet w rewolucji amerykańskiej. Amerykanki preferowały metodę epistolarną, koncentrując się na listach i petycjach. Doskonałym przykładem jest Abigaile Adams, żona późniejszego prezydenta, która mimo że nie miała duszy rewolucjonistki i akceptowała tradycyjny podział ról na zasadach wówczas obowiązujących, to w 1776 roku rozpoczęła kampanię na rzecz praw kobiet. W liście do męża pisała; „,[...] powinniście myśleć o kobietach i traktować je wspaniałomyślniej i korzystniej, niż to czynili wasi przodkowie. Nie dajcie nieograniczonej władzy mężom. Pamiętajcie - wszyscy mężczyźni byliby tyranami, jeśli mogliby. Jeśli kobiety nie znajdą żadnych szczególnych względów, jesteśmy zdecydowane wzniecić bunt. Nie będziemy przestrzegać praw, w których nie mamy głosu i reprezentacji” (Stelmasiak, s. 109) - groziła. Te słowa przyszłej prezydentowej oddają istotę protestów kobiet w XVIII i XIX wieku - jest nią potrzeba faktycznego udziału w podejmowaniu decyzji politycznych o charakterze ogólnonarodowym. Hasło „nic o nas bez nas” zostało wprawdzie sformułowane jako zasada demokracji szlacheckiej w Polsce, lecz lapidarnie definiuje generalną przyczynę protestów kobiet. Adams oczekiwała również, że amerykańska Karta Praw uwzględni prawo do kształcenia kobiet. Ubolewała, że Amerykanki nie mają równego dostępu do nauki, mimo że „Kobiety uczestniczą w wielkim teatrze życia [...]. Powinny więc być do tego przygotowane" (cyt. za: Stelmasiak, 1999, s. 111).

W działalności na rzecz praw kobiet Abigail Adams wspomagała Mercy Otis Warren - poetka i publicystka, zagorzała obrończyni republiki. Tak jej życie, jak i twórczość wpisują się w towarzyszący amerykańskim kobietom dylemat: wzrostu świadomości równościowej i tradycyjnych ról kobiecych. W przypadku Warren problem ten ujawnia się poprzez nadgorliwość w pokorze wobec kobiecego intelektu (Wheeler, 2013, s. 94-96). Mimo że również twórcy amerykańskiej konstytucji zapomnieli o kobietach, to w Stanach Zjednoczonych narodził się ruch 
feministyczny. Co interesujące to fakt, ze Amerykanki otrzymały prawa wyborcze dopiero w 1920 roku na mocy 17. poprawki do Konstytucji. Pięćdziesiąt lat wcześniej uchwalono 15. poprawkę, na mocy której zabroniono ograniczania praw wyborczych ze względu na „rasę, kolor skóry lub poprzednie niewolnictwo". W okresie rewolucji te dwa zagadnienia traktowane były niejako en bloc. Obie grupy społeczne: kobiety i czarnoskórzy mieszkańcy Ameryki Północnej, funkcjonowały na marginesie życia publicznego. Obie przysłużyły się oderwaniu od Korony, obie były zaangażowane w wojnie secesyjnej, przyczyniając się znacząco do zwycięstwa Północy. Jednak przyznanie praw wyborczych kobietom stanowiło poważniejsze wyzwanie, niż nadanie prawa do głosowania ciemnoskórym mężczyznom.

Mimo to, to właśnie Stany Zjednoczone stały się kolebką ruchu feministycznego. XIX wiek okazał się przełomowym pod tym względem, ponieważ obfitował w przykłady kobiecych protestów, czy w formie czynnych manifestacji, czy też odważnych publikacji (np. Marion Reid, Lucretia Mott). W 1848 roku Elizabeth Cady Stanton, pod wpływem incydentu podczas kongresu abolicjonistycznego w Europie (najpierw wykluczono możliwość uczestnictwa kobiet w obradach, później - pozwolono im się jedynie przysłuchiwać dyskusji), umieściła w lokalnej gazecie Seneca Falls ogłoszenie. Było to zaproszenie na spotkanie skierowane do wszystkich kobiet, które nie tylko dostrzegają niesprawiedliwe traktowanie, ale chciałyby to zmienić. Zainteresowanie spotkaniem przerosło oczekiwania Stanton. W ten sposób w 1848 roku, w Seneca Falls narodził się ruch na rzecz równouprawnienia kobiet.

Szeroki odzew na hasła sufrażystowskie w Stanach Zjednoczonych był konsekwencją krótkiej historii tego kraju. Zbudowane na prawnonaturalnej koncepcji wolności i równości, w wydaniu Johna Locke’a, państwo miało komfort eksperymentu stworzonego od podstaw, bez feudalnych i absolutystycznych obciążeń. Ponadto Stany Zjednoczone, u swego zarania, były krajem emigrantów, którzy opuścili swoje ojczyzny w poszukiwaniu równości i wolności (Ślęczka, 1999, s. 58-59). Wartości te nie były więc dla nich jedynie hasłami.

Istotny wpływ na aktywizację Amerykanek miała również religia. Większość pionierów amerykańskiej niepodległości była wyznań protestanckich. Niektóre wspólnoty religijne (np. pietyści, kwakrzy i szejkersi, metodyści), które wprawdzie narodziły się w Europie, w Nowym Świecie znalazły dla siebie sprzyjające środowisko, radykalizując się w swych poglądach liberalnych - w tym - na kwestię udziału kobiet w Kościele. 
Reformacja drugiej fali, w połączeniu z owym „brakiem obciążeń”, stworzyła sprzyjające warunki dla rozwoju świadomości równościowej. Dlatego te same nurty religijne, w Wielkiej Brytanii czy w Niemczech, nie przyniosły równie wczesnej autonomizacji kobiet, choć 1848 rok był dla Europejek równie ważny jak dla Amerykanek spod znaku Seneca Falls. Polityczny i społeczno-ekonomiczny ferment wywołany zdarzeniami Wiosny Ludów, wpłynął również na aktywizację kobiet poprzez działalność pisarską i organizacyjną. Powstają liczne pisma manifestujące oczekiwania kobiet względem praw wyborczych, ale również sprawiedliwego pozycjonowania kobiety w rodzinie. Coraz śmielsze wystąpienia kobiet wywoływały reakcję nie tylko w środowiskach konserwatywnych. Na przykład pisma Williama Thomsona i Anne Wheeler, wzywające do buntu kobiet przeciwko domowej niewoli, spotkały się z reakcją, liberalnego, zdawałoby się, Carla Welckera, który powielał, powtarzane od wieków, argumenty, odwołując się do „wrodzonej” słabości kobiecej.

Aktywizacja Europejek na poziomie organizacyjnym zamykała się wszelako w obszarze tradycyjnych ról kobiecych. Powstawały więc liczne organizacje charytatywno-opiekuńcze, częstokroć powiązane ze wspólnotami religijnymi. Miały one stanowić szkołę dla przyszłych aktywistek ruchu feministycznego. Choć, oczywiście, dla części kobiet stanowiły docelową formę samorealizacji.

Rozwój socjalizmu - z jednej strony - i ruchów narodowowyzwoleńczych - z drugiej determinował nie tylko treść, ale również formę aktywności kobiet. Postulatom dostępu do edukacji i możliwości podnoszenia kwalifikacji towarzyszyły hasła godziwego wynagrodzenia za pracę; żądaniom praw wyborczych dla kobiet - oczekiwania zmian obyczajowych. Również uwikłanie w bieżącą politykę określało cele aktywistek. W Polsce była to walka o niepodległość, którą w kobietystycznych organizacjach łączono z pozytywistyczną pracą u podstaw - a więc, w tym przypadku, edukacją. Przykładem owego zespolenia celów edukacyjnonarodowowyzwoleńczych były entuzjastki z Narcyzą Żmichowską na czele.

Na początku XX wieku najbardziej aktywnym, a jednocześnie - najbardziej kontrowersyjnym środowiskiem równościowym były brytyjskie sufrażystki. Coraz częstsze i coraz liczniejsze protesty napotykały na coraz radykalniejszą reakcję władz i coraz bardziej nieprzychylny odbiór społeczny. Dochodziło do starć z policją i napiętnowania sufrażystek z ambon kościelnych. Jednak to nie głoszone hasła (bo o prawie wyborczym dla kobiet mówiono przecież od ponad wieku), lecz poziom 
zaangażowania oraz forma aktywności niepokoiły konserwatystów - tak mężczyzn, jak i kobiety.

Symbolem angielskich sufrażystek stała się Emeeline Pankhurst, która w 1903 roku, wraz z córkami, powołała do życia Women's Social and Political Union (WSPU). Kobiety, skupione w tej organizacji, zaczęły posługiwać się metodami, które poczytywano za zagrożenie porządku społecznego. I znów - nie dlatego, że przerywanie politycznych zebrań, wdzieranie się do Izby Gmin było czymś dotąd niespotykanym, ale fakt, że uczestniczkami i inicjatorkami zajść były kobiety - bulwersował najbardziej. Kulminacja aktywności sufrażystek nastąpiła w 1910 roku. W piątek 18 listopada sufrażystki zorganizowały manifestację przed parlamentem brytyjskim. Zgromadzenie usiłowała rozpędzić policja, bijąc uczestniczki, polewając je woda, tratując końskimi kopytami. W wyniku tych zajść wiele kobiet doznało ciężkich obrażeń, a dwie z nich zmarły. Ponad 150 uczestniczek aresztowano. Ze względu na skalę dramatu, który rozegrał się na ulicach Londynu, dzień ten nazwano „czarnym piątkiem”. Dramat sufrażystek jednak się nie zakończył. Kobiety osadzone w więzieniu były bite i upokarzane, a te, które podejmowały strajk głodowy - karmione siłą. Tragedia „czarnego piątku” nie odstraszyła sufrażystek. Wręcz przeciwnie - radykalizacji uległy metody służące zwróceniu publicznej uwagi na problem nierówności płci. Coraz częściej dochodziło do aktów wandalizmu, a niektóre z nich były w swym barbarzyństwie niezwykle spektakularne. W 1914 roku Kanadyjka, Mary Richards, zniszczyła w Galerii Narodowej w Londynie obraz Vélazqueza „Wenus z lustrem". Rok wcześniej Emily Davison rzuciła się pod końskie kopyta w trakcie wyścigu na hipodromie w Surrey. Zmarła w wyniku odniesionych ran (Bogucka, 2005, s. 266-267).

Manifestacje, petycje, akty wandalizmu, samobójstwa - za pomocą tych metod kobiety XIX i XX wieku walczyły o uwagę spatriarchalizowanego społeczeństwa - uwagę, która była warunkiem sine qua non zmian na poziomie rozwiązań legislacyjnych. Zmiany świadomościowe były kwestią edukacji, a nie przepisów prawa i ich wprowadzenie było znacznie trudniejsze i długotrwałe.

Mimo że protestujące kobiety były przedmiotem krytyki, szyderstw, a nawet przemocy (tak ze strony osób prywatnych, jak i ze strony państwa), to ich determinacja przyniosła efekty w postaci praw wyborczych, które od lat 90. XIX zaczęły stopniowo pojawiać się w ordynacjach wyborczych. Czynnikiem wyzwalającym była również I wojna światowa. Jej zasięg i forma eliminowały na wiele lat mężczyzn z dotychczaso- 
wego życia zawodowego czy publicznego. Wakaty zapełniały kobiety, udowadniając tym samym, że dorównują umiejętnościami mężczyznom. Po zakończeniu wojny ich pozycja ponownie uległa pogorszeniu z dwóch powodów: po pierwsze - powrót mężczyzn z frontu uniemożliwił im kontynuację karier, a po drugie - przyznanie praw wyborczych, w oczach mężczyzn, miało ostatecznie rozwiązać problem kobiecych aspiracji. Zmiany, które nastapiły miały jednak wyłącznie charakter prawny, a nie świadomościowy. Definiowanie ról kobiecych nadal opierało się na tradycji patriarchalnej, sytuując kobietę w kontekście macierzyńskim i rodzinnym.

W ciagu trzystu lat eksperymentów organizacyjnych, kobiety odkryły możliwości tkwiące $\mathrm{w}$ działaniach gremialnych. Kryzys demokracji i narodziny dyktatorskich systemów europejskich (Niemcy, Włochy, Rosja, Hiszpania, Portugalia, Grecja, Francja), na wiele dziesięcioleci zahamowały wyzwalającą się inicjatywę. Co prawda wielu dyktatorów prowadziło pronatalistyczną politykę, ale była ona definiowana w oparciu o androcentryczną wizję społeczeństwa. Autorytarne reżimy zezwalały wprawdzie na aktywność organizacyjną kobiet, ale opierała się ona na narzuconym schemacie, utrwalającym panującą władzę (kobieca Falanga w Hiszpanii, Unia Narodowa Kobiet w Portugalii, w Niemczech Deutsche Frauenschaft czy Związek Niemieckich Dziewcząt). Bolszewizm radziecki wykluczał wprawdzie powstawanie alternatywnych względem KP ZSRR organizacji, lecz tworząc społeczeństwo nowego wzoru, wygenerował model kobiety przodowniczki: pierwszej w pracy i w domu, sprowadzonej do roli przedmiotu w spatriarchalizowanym środowisku społecznym i politycznym. Swoboda seksualna, łatwy dostęp do aborcji i rozwodów - były rozwiązaniami, które utrwalały dyskrtyminację, prowadząc do podwójnego zniewolenia kobiet - przez ideologię i przez mężczyzn (Bogucka, 2005, s. 283-286).

Druga wojna światowa, podobnie jak pierwsza, odegrała rolę katalizatora tłumionych potrzeb kobiet. Po jej zakończeniu, w krajach które wybrały drogę demokracji, zaczęły odradzać się dawne organizacje kobiece i powstawać nowe. Erupcja aktywności kobiet nastąpiła w latach 60. XX wieku. I tym razem inicjatorkami masowych kontestacji były Amerykanki. Ich bunt przeniósł się wkrótce za Ocean, do Francji, Niemiec i Wielkiej Brytanii, co wiązało się z wejściem na kolejny poziom świadomości równościowej. Kobiety protestowały przeciwko uprzedmiotowieniu; przeciwko sprowadzaniu ich istnienia do rangi obiektu seksualnego. Oprotestowano więc wybory Miss Ameryki w 1968 roku, podpalano stosy z kosmetykami i lokówkami, a na cmentarzu a Arlington 
urządzono pogrzeb „tradycyjnej kobiecości”. Również Brytyjki buntowały się przeciwko organizacji wyborów Miss Uniwersum. Francuzki pod Łukiem Triumfalnym złożyły wieniec z napisem „Nieznanej żonie nieznanego żołnierza”, a kobiece bojówki napadły na redakcję „Elle”. Natomiast Holenderki organizowały protesty, które często przybierały formę happeningów, a niemieckie aktywistki obrzucały pomidorami przeciwników wyzwolenia kobiet (Bogucka, 2005, s. 291).

Umasowienie kobiecych buntów w latach 60. i 70. XX wieku było wyrazem reinwencji świadomości równościowej. Wszelako poczucie strukturalnej niesprawiedliwości na poziomie płci od kilkuset lat znajdowało ujście w różnych formach protestu. Początkowo nierozpoznana czy też nieuświadomiona motywacja pierwotna była wprawdzie ukryta pod celami ekonomicznymi i politycznymi, stopniowo jednak, początkowo w środowiskach kobiet wywodzących się z klas wyższych, anamnestycznie wyłaniała się w tekstach, hasłach i debacie. Zaważyło to na zaangażowaniu buntowniczek spoza warstw uprzywilejowanych, które wprawdzie nie posiadały odpowiedniego wykształcenia, lecz nie zatraciły przecież umiejętności myślenia.

\section{Bibliografia}

Allen T. (1827), The History and Antiquities of London, Westminster, Southwark, and Part Adjacent, vol. 1, Cowie and Strange, London.

Bessiéres Y., Niedzwiecki P. (1991), Women in the French Revolution: Bibliography, Women of Europe Suplements, no. 33.

Bogucka M. (2005), Gorsza płeć. Kobieta w dziejach Europy. Od antyku po wiek XXI, Wydawnictwo Trio, Warszawa.

Delonnette H. (2002), Did the Civil War and Its Aftermath to 1660 Offer Any Lasting New Opportunities to Women?, „Cromwelliana: The Journal of The Cromwell Associacion", Cambridgeshire Heritage, Cambridge, ss. 37-43.

Font Paz C. (2013), "The Cure of the Kingdome": Defending Female Authorship in Elizabeth Poole's a Vision (1648), „Revista de Filologia Inglesa”, no. 34, ss. $179-191$.

Gałażewski J. (2013), Pani Roland i trauma Rewolucji, „Napis”, nr XIX, ss. 41-52.

Garrioch D. (1999), The Everyday Live sof Parisian Women and the October Days of 1789, „Social History”, vol. 24, no. 3, ss. 231-249.

Godineau D. (1998), The Women of Paris and Their French Revolution, University of California Press, Berkeley-Los Angeles-London.

Levy Darling G., Applewhite H. B., Johnson M. D. (red.) (1980), Women in Revolutionary Paris 1789-1795, University of Illinois Press, Urbana-Chicago. 
Moore L. (2007), Liberty: The Lives and Times of Six Women in Revolutionary France, HarperCollins Publishers, New York.

Proctor C. E. (1990), Women, Equality, and the French Revolution, Greewood Press, Conecticut.

Read S. (2015), A Women's Revolt, „History Today”, August.

Reid J. S. (1834), The History of the Presbyterian Church in Irland, compraising The Civil History of the Province Ulster, from the Accession of James The First, Balfour and Co. Niddry Street, Edinburgh.

Stelamsiak K. (1999), Wydarzenia rewolucji amerykańskiej roku 1776 w oczach Abigail Adams, „Acta Universitas Lodziensis. Folia Historica”, nr 64, ss. 101-115.

Ślęczka K. (1999), Feminizm. Ideologie I koncepcje społeczne współczesnego feminizmu, Wydawnictwo „Książnica”, Katowice.

Walton G. (2016), Théorgine de Méricourt, Heroine of the Frencz Revolution, www. amazingwomenhistory.com/theorgine-de-mericourt.

Wheeler M. (2013), Mercy Otis Warren, The Historiographical Motivation of an Unlikely Patriot, ,Saber and Scroll”, vol. 2, Issue 4, ss. 83-99, http://digitalcommons.apus.edu/saberandscroll/vol2/iss4/8.

Wysłobłocki T. (2013), Zapomniana płeć - jak Rewolucja Francuska nie chciała pamiętać o kobietach, „Acta Universitatis Lodziensis. Folia Litteraria Romanica", nr 8, ss. 223-231.

Zemon Davis N. (1975), Women on Top, w: Society and Culture in Early Modern France: Eight Esseys by Natalie Zemon Davis, Stanford University Press, Stanford, California, ss. 125-151.

\section{Women's Rebellion: in Search of the Sources of Awareness of Gender Equality (17th century to the 1960s)}

\section{Summary}

The 20th century is sometimes called the „century of women.” Feminism of the second wave, preceded by the involvement of suffragists and their effective fight for political rights, accelerated the process of shaping women's self-consciousness. However, this process started much earlier. The 19th century protests of emancipated women had been preceded by a hundred-year history of women's rebellions. Although their motivation at the stage of contestations in the 17 th and 18 th centuries was primarily economic and political, and they only supported men's activity, still the reflection on the inadequacy of social contribution of women and their actual participation was born. This article is therefore devoted to these timid beginnings of the revived awareness of equality, expressed in various forms of rebellion and protest.

Key words: feminism, women, social movements, social protest, equality awareness, equality 
